\title{
Thinking about Aging: Experience, Identity and Meaning among an Elderly Population in the Philippines
}

\author{
Rolando C. Esteban \\ Department of Anthropology, College of Social Sciences and Philosophy, University of the Philippines, Diliman, \\ Quezon City, Philippines \\ Email: rcarbest@yahoo.com
}

Received 3 July 2015; accepted 15 August 2015; published 18 August 2015

Copyright @ 2015 by author and Scientific Research Publishing Inc.

This work is licensed under the Creative Commons Attribution International License (CC BY). http://creativecommons.org/licenses/by/4.0/

c) (i) Open Access

\section{Abstract}

The paper aims to know the idioms that the elderly use to describe and make sense of their experience of aging. It is based on ethnographic data gathered through the in-depth interview of 30 normal and community dwelling elderly in Marikina City, Metro Manila, Philippines in 2012-2013. The participants were chosen through compulsive sampling from the registry of 1385 senior citizens screened free from dementia. Their age ranged from 60 to 90 years, regardless of social class, gender, ethnicity, religion and other indices of difference. The interviews were transcribed, verbatim, and coded for the idioms, their meanings and contexts in which the elderly used them. The elderly communicate in idioms, which maybe basic to denote identity that obtains from aging or secondary in that they develop from the basic ones and help define identity further. The idioms relate to either continuity or discontinuity theory of aging or help rationalize what it means to be human and elderly.

\section{Keywords}

Aging, Elderly, Idioms, Agency, Frames

\section{Introduction}

The various fields of specialization that deal with aging define the concept quite differently [1]-[4]. No matter the difference, the idea that aging is the process of growing old seems to have currency [5]. There is agreement as well about aging as an individual and demographic process [6] [7]. Individual aging is old, while demographic aging is new [8]. Individual aging is a biocultural process that involves the transformation of the individual 
from "youth" to "elder" [9]. In this process, the elderly crystallize aspects of culture that have selective advantage and transmit them to the next generation [10]. Culture here refers to a system of meanings acquired, accumulated and transmitted throughout the individual's lifetime [9]. Demographic aging is characterized by the rise in the number of the elderly in the population due to low birth and morality rates [11] [12]. It involves the survival of more and more individuals into late life who constitute elderly populations all over the world.

Global aging is an effect of the "demographic transition" that started in England during the Industrial Revolution [11] [12]. Better living conditions that the Industrial Revolution catalyzed, together with improvements in public health, the rise of laboratory medicine and beliefs and values, facilitated the transition [13]. The transition was an uneven process that depended on the country's past birth and mortality rates. Expectedly, England completed the transition in the 1850s [14], while the United States experienced the phenomenon in the 1900 [15]. Japan, the oldest population in Asia, made the transition in post-WWII [16], while the Philippines made it in the 1970s [17]. Thus, countries in the developed world are "old", while those in such developing regions as Africa, South America, South Asia and Southeast Asia are "young” but aging fast [18].

The effects of population aging on individuals, societies and governments are still largely unknown. Nonetheless, experts, governments and global organizations express alarm about the pressures that aging exerts on two critical policy areas, namely, the pension systems and health services. Pension can help caution the impact of reduced income in late life [19], while the demand of the elderly for healthcare could compromise the health needs of younger age groups. Research in these areas is just beginning to emerge, showing, for example, how some countries in the developed world are revising their established pension and health policies toward agingfriendly societies [20]-[22].

Notwithstanding this, it is also important to understand aging as an individual experience. However, we cannot study “'experiencing' — or experience in real time and its physical, mental, and emotional constituents and therefore must study retrospective accounts-linguistic representations” ([23], p. 173). Experience refers to all actions, including "mental states or acts as opposed to descriptive expressions of common and ordinary experience, which may or may not express such states or acts” ([24], p. 26). Ferrater-Mora and Cohn [24] argue that individuals describe their experience using words, while Yamane [23] insists that words are interpretations of experience. I suggest, though, that words are description and at the same time interpretations of experience. Some words function as basic idioms, or frames, the conventional ways by which individuals express their feelings and thoughts [25].

\section{Methodology and Theoretical Framework}

This study is an analysis of ethnographic data gathered through the in-depth interview of 30 normal and community dwelling elderly in Marikina City, Philippines in 2012-2013 [26]. They represent a population chosen through compulsive sampling from the registry of 1385 senior citizens screened free from dementia [27]. The interviews were transcribed, verbatim, and content analyzed through "substantive coding" as suggested by Strauss and Corbin [28] to determine the idioms or frames [25]. The analysis probes into the meanings of these idioms and the contexts in which these idioms are used [23]-[25]. Relevant concepts [26], models of and approaches to aging inform the analysis [9] [29]. The remainder of the paper is written in the ethnographic presents because of the synchronic nature of the analysis. The St. Luke's Medical Center Ethics Board issued the ethics clearance for the research protocol. The participants understood the nature, methods and objectives of the protocol, and they freely agreed to participate in the research by signing the free prior informed consent form before the interview. They agreed as well to the presentation of the findings of the research in conferences and the publication of same findings in a variety of forms, provided they remain anonymous. Their names have beenchanged to ensure their rights to anonymity.

\section{Findings}

As shown in Table 1, the demographic characteristics of the participants maybe stated, as follows: their age ranged from 60 to 90, with a Mean of 71.93 and a Standard Deviation of 8.39; 25 are females and 5 are males; 21 are widows or widowers; 8 are living with their spouses; and 1 is never married. In terms of living arrangement, 23 prefer co-residence or living with their children: 21 choose to move into the households of their children; and 2 choose to invite their children to their households. Seven prefer independent residence or living apart from their children: 5 live in their households as couples; 1 lives with a caregiver; and 1 lives with a grand- 
daughter. Except for a female who is never married and has no child, 29 are married, whose number of children range from 3 to 9, with a Mean of 4.36 and Standard Deviation of 1.95. Their education or number of years spent in school range from 6 to 14 years, with a Mean of 6.27 and a Standard Deviation of 3.17.

Table 2 shows the idioms that the elderly use to communicate their feelings and thoughts about aging. Two of these idioms are basic in the sense that they denote identity due to aging, namely, tulad ng dati and di tulad ng dati. Another 10 of these are secondary in that they obtain from the basic ones and help define identity further. These are kabataan, bata pa, malakas pa, kaya pa, malusog, katandaan, matanda na, mahina, di na kaya and sakitin. Tulad ng dati, in the sense of kabataan, bata pa, malakas pa, kaya paand malusog, relate to continuity theory of aging, while di tulad ng dati, in the sense of katandaan, matanda na, mahina, di na kaya and sakitin, relate to discontinuity theory of aging. The last of these, sa awa $\mathrm{ng}$ Dios, is a rationalization of what it means to be human and elderly.

\subsection{The Life Course: From Kabataan to Katandaan}

Various models of the body as an organic entity exist, two of these need specific mention because of their relevance to the study. Katz [8] proposes a two-stage biocultural model that shows aging as a transition from an "earlier" to a "later" stage. The earlier stage is a movement from conception to sexual and reproductive maturity, while the later stage is a movement from menopause to post-reproductive longevity. Robertson [9] tries to im-

Table 1. Descriptives of participants.

\begin{tabular}{|c|c|c|}
\hline & Descriptive & Frequency \\
\hline \multirow{2}{*}{ Gender } & Female & 25 \\
\hline & Male & 5 \\
\hline \multirow[t]{3}{*}{ Civil Status } & With spouse & 8 \\
\hline & Widow/er & 21 \\
\hline & Single & 1 \\
\hline \multirow{3}{*}{$\begin{array}{l}\text { Living Arrangements } \\
\text { Independent }\end{array}$} & With caregiver & 1 \\
\hline & With spouse & 5 \\
\hline & With relative & 1 \\
\hline \multirow{3}{*}{ Co-resident } & Children taking in elderly & 21 \\
\hline & Elderly taking in children & 2 \\
\hline & Mean & Std. Dev. \\
\hline Age & 71.93 & 8.39 \\
\hline Education & 6.27 & 3.17 \\
\hline Number of children & 4.36 & 1.95 \\
\hline
\end{tabular}

\section{Table 2. Idioms.}

\begin{tabular}{|c|c|c|c|c|}
\hline \multicolumn{5}{|c|}{ Classification of idioms } \\
\hline & Tagalog & English & Tagalog & English \\
\hline Basic & tulad ng dati & like before & di tulad ng dati & unlike before \\
\hline Secondary & $\begin{array}{l}\text { kabataan } \\
\text { bata pa } \\
\text { malakas pa } \\
\text { kaya pa } \\
\text { malusog }\end{array}$ & $\begin{array}{c}\text { youth } \\
\text { still young } \\
\text { still strong } \\
\text { still able } \\
\text { healthy }\end{array}$ & $\begin{array}{l}\text { katandaan } \\
\text { matanda na } \\
\text { mahina } \\
\text { di na kaya } \\
\text { sakitin }\end{array}$ & $\begin{array}{c}\text { old age } \\
\text { already old } \\
\text { weak } \\
\text { unable } \\
\text { sickly }\end{array}$ \\
\hline Rationalization & sa awa ng Dios & by the grace of God & & \\
\hline
\end{tabular}


prove on this by proposing a three-stage, intergenerational model where the ascending generation begets the individual who, in the process of maturation, begets the descending generation. The life stages are birth, maturation and death. Robertson describes the model, saying, “The early stages of life are concerned emphatically with its (culture, underscoring mine) acquisition, the middle stages with its consolidation in social experience, the later stages with its formal definition and transfer” ([9], p. 226).

The idea that the life course is a model of aging obtains from acute observations of the changes that the body and its processes and capacities undergo throughout a lifespan. These changes account for views of aging as a transitions from an "earlier" to a "later" stage [4] or from "youth" to "elder" [9]. These views are compatible with the way the elderly think about aging. Talk of aging elicits references to the process as a movement from kabataan to katandaan. Kabataan is a changeover from birth to maturity, the prime of life, described as a body that is physically strong, healthy and productive. Katandaan is a changeover from maturity to senescence that refers to late life, described as a body that is physically weak, prone to disease and less productive.

\subsection{Continuity: Tulad ng Dati}

Continuity presupposes that aging is a movement on the life course that links the past, present and future. It is an effect of the narration of identity, which involves transitions from birth to maturity to senescence. It is multifarious, vigorous and affects individuals differently. Some elderly think that they are youthful, still young to emphasize aging as a continuous process. Manolito, who is 70 years old, thinks that he is not old because, as he says it, "Bata pa ako" (I am still young) in the sense of "Malakas pa ako, kaya ko pa" (I am still strong; I can still do it). By malakaspa and kaya pa, he means that he is still capable of activity because he is still healthy and strong. He does not take maintenance medication for hypertension, diabetes or any chronic disease. Activity refers to IADL not ADL or paid work because he is not frail, he is past the employable age, and no paid work for the elderly like him exists in the city. The impact of aging on the relationship between age and work ability remains largely understudied all over the world. Ilmarinen ([31], p. 3) postulates that since individuals have longer lives today than in the past, “work ability should start, at the least, with people aged 30-35”. This idea, when put to practice, can radically alter the age cap for employment, extend retirement to later years and enable the elderly to squirrel away more resources for post-retirement life. This, however, needs to be weighed against the observation that as they advance in years, the elderly either desist from engaging in strenuous jobs or prefer mental ones [32].

Tulad ng dati implies that the life course is a continuous process. It is, however, ambivalent because it asserts youthfulness and accepts aging at the same time. Tulad ng dati, as bata pa, obtains from a sense of youthfulness that tries to subvert the image that society creates for old people. His wife Zenaida kids Manolito about it, saying, “Ayaw tumangap na sya ay senior na" (He refuses to accept that he is already a senior citizen). He does not mention that he is old, and he avoids talk about himself as an elderly person. He does not say that he is bata (young); he says, instead, that he is bata pa. It is in this sense, and to a limited extent only, that tulad ng dati, as bata pa, finds resonance in Kaufman's concept of “ageless self” [29].

The idea of "ageless self” argues for a body image that is independent of chronological age that obtains from the continuous narration of one's life. "Continuous restructuring [of identity] allows individuals to maintain a feeling of unity about themselves and a sense of connection with the parts of their pasts they consider relevant to who they are at the present” ([29], p. 150). Individuals adapt to changing circumstances by maintaining, “existing internal and external structures" ([33], p. 183). It is retrospective: it looks at life as a continuous process across the life course, linking the past, the present and the future. It is a mental state as well as action, "a grand adaptive strategy that is promoted by both individual preference and social approval” ([33], p. 183).

More specifically, continuity refers to capacity for IADLs. The elderly believe that activity can delay, if not prevent, the onset of disease, including dementia [34]. Zenaida makes a clear point about this, saying "Malakas pa ako, kaya ko pa, umiigib pa ako ng tubig (I am still strong, I can still do it, I still fetch water). This articulates an aspiration for a life independent from her children or, at least, to live separately from them because she can still care for herself. She underscores this by calling attention to an activity for which she still has the strengthfetching water, a woman's role that many men do because it is mabigat (heavy) for women.

IADLs reflect a gender schema that differentiates strenuous from non-strenuous activities. For men, strenuous activity includes driving, lifting heavy objects, playing basketball, etc. Non-strenuous activity includes hobbies that they did not have the time to do in their youth because of work, parenting roles and other obligations. Emi- 
lio, a 64-year old former cab driver, is still capable of all these, including visiting friends alone. He also believes that he can defend himself against the siga (toughies) in the streets and in the neighborhood. However, since his children do not let him drive anymore, he busies himself with carpentry and carving at home. Gaudencio, who is 74 years old, is still active as a campaign manager of a local politician, he still writes campaign materials, and he still serves as emcee during election campaigns.

The difference between strenuous and non-strenuous activities for women is ambiguous. Such chores as cooking, cleaning, doing the laundry, going to the market, childcare, fetching water, etc., women continue to perform in old age. However, as women advance in years, it appears that doing the laundry and fetching water can be too arduous to some, and those who can still do these chores could be exceptions like Arsenia, who is 78 years old. Arsenia lives with a married child who, together with her other children, do not let her live alone because they believe that she is no longer capable of living by herself. They provide her company whenever she consults with the doctor, visits relatives or vacations in the province to keep her safe from accident and harm. On the contrary, she believes that she is still healthy, strong and capable of living independently from her children. She tries to convince family members about this because, after all, she does the grocery, cooks for the entire household, takes care of the young and washes her own clothes and those of her grandchildren too.

\subsection{Discontinuity: Di Tulad ng Dati}

Not everyone agrees with the continuity theory. Tulad ng dati, as bata pa, malakaspa, kaya pa, malusog, creates an image of the elderly that is neither old nor young but something in between, which is midlife, not the years prior to it as maybe the misconception. The story of Winifrida, who is 70 years old, and many others contest this: human beings grow old, a process marked by progressive declines in physical prowess, health and reproductive capacity. Activity decreases as the individual advances in years regardless of the will for action. Ayabe et al. say ([35], p. 425), "The intensity of daily physical activity decreases with increasing age regardless of the amount of daily physical activity". Moreover, following the death of a spouse, studies of "second couplehood" would show that, "Continuity was experienced as the exception and discontinuity as the rule" ([36], p. 687).

Some elderly state that they are matanda na to emphasize aging as a discontinuous process. Discontinuity presupposes a movement on the life course, stage by stage, with each stage marked by changes that differentiates the young from the old. It is a conventional, Darwinian view of aging that underscores the reproductive role of the individual in the species. It considers aging as senescence and characterizes it as a stage in life marked by decreases in health, activity and productive prowess [9]. In addition to this, ageist views mark late life with inactivity, disease, social withdrawal, poverty, decrepitude and feebleness [37] [38]. On the contrary, activity, health, gainful work, connectedness and agency show the elderly as a diverse population and aging as a multifaceted and vigorous process that affects individuals in profound ways.

Activity indexes katandaan, which refers to ADLs, IADLS, volunteerism or gainful work. Although they differ from country to country, ADLS and IADLs generally try to measure the capacity of the individual for activity in late life [39]. ADLs refer to such self-care tasks as eating, bathing dressing, toileting, transferring and continence [40]. IADLs refer to chores [39], which, in Philippine context, include going to market, preparing food, doing the laundry, house cleaning, driving, taking the bus or train, fetching water, etc. Volunteerism refers to unpaid work for an organization [41], while gainful work refers to self-employment [42] or paid work in the government or in the private sector [31].

Winifrida is a strong and healthy widow, but her children insist that she live with one of her daughters so that she can take care of her. She is ambivalent about co-residence: she is happy that her children care for her, but she expresses a desire for independent residence at the same time. She amplifies this by insisting on her capacity for such IADLs as cooking and doing the laundry and by complaining about meat in the food that she tries to avoid for health reasons. She says, "Naglalaba ako ng damit ko, nagluluto ako mag-isa. Gusto kung humiwalay sa kanila dahil natutukso ako minsan pag yung may mga karne sila” (I wash my clothes, I cook my food. I want to live alone because sometimes I cannot avoid eating meat that they prepare). Despite her capacity for IADLs, she considers herself old because of her chronological age. She says, "Matanda na ako, kaya nga kung minsan naglibang-libang na lang ako sa pamamagitan ng panunuod ng sine, ng TV" (I am already sold, so sometimes I entertain myself by watching movies and television). Women like her struggle against stereotypes that portray the elderly as socially withdrawn, depressive and unproductive in various ways (Cornwell and Waite, 2009). An accepting attitude toward growing old enables Winifrida to cope with inactivity and sadness. She keeps a net- 
work of friends who meet together whenever they watch free movies for the elderly in theaters in the city on Mondays and Tuesdays. Friends are a source of information for activity that she may find interesting for involvement.

Activity is a bodily impulse, hinahanap ng katawan, something that the body looks for, which relates to wellbeing [44]. It brings relief to body pains that inactivity causes. Tanita's health management approach against body pains due to inactivity involves going to and from the market on foot. She says, "Sumasakit yung katawan ko pag lagi lang nakaupo, ah naglalakad ako pamalengke, sa umaga naglalakad ako hanggang palengke nilalakad ko" (My body aches when I am always seated, so in the morning I walk to and from the market). Seitsamo and Klockars ([45], p. 27) posit that, "Health is not merely the absence of disease, it is a dynamic and harmonious balance between a person’s psychological surroundings, the natural environment, and the social network”. On the contrary, the elderly hold on to the idea of health as absence of disease and disease as naturally occurring phenomenon. Isabelita says, “Talagang ganyan. Minsan malusog, minsan may sakit” (Life is like that. Sometimes we are healthy; sometimes we are sick). What then is a healthy body? The way Perfecta describes her health is instructive. She says, "Hindi ako sakitin. Hindi ako ubuhin, hindi ako sipunin" (I am not sickly. I am not prone to cough and colds).

Women usually have negative perceptions of health status and role functioning in late life [46]. Nevertheless, an accepting attitude towards disease helps foster positive health management approaches [47]. It is possible then for a sufferer of chronic disease to feel happy. Except for emphysema, Pablito is healthy and happy because he does not take maintenance medicines. A silent man, he lets his wife Mercedita speak for him. She says, "Sa awa ng diyos naman si Pablito malusog. May maintenance ako sa high blood at saka diabetes, sya wala. Ako may rayuma, sya wala" (By the grace of God, Pablito is healthy. I have maintenance drug for high blood and diabetes but he has none. I have rheumatism but he has none). A healthy body then is not sickly, it is not prone to such common ailments as cough and colds, and it does not succumb to dementia.

Dementia is "a group of neurodegenerative disorders characterized by progressive loss of cognitive function and a decrease in the ability to perform activities of daily living” [48]. It is due to several causes, the most common of which is Alzheimer's disease (AD) [49]. Progressive decline in memory, linguistic problems and behavioral changes signal dementia. When asked about what she knows about dementia, Pelagia, who is 70 years old, understands it as forgetfulness. She narrates her experience, saying, "Kasi ako, alam kong sasabihin ko, eka nga, malalim hindi ko na masabi. Makaraan ang ilang araw maalala ko na" (I know what to say but I cannot. After a few days, I can recall it). Marking dementia with memory loss is understandable because society gives importance to cognitive decline more than any other symptom of dementia.

Dementia (Tagalog, ulyanin) is associated with normal aging. It is characterized by such changes in behavior as malimutin (forgetful), makulit (importunate) and naliligaw (wandering). These and other markers describe dementia that maybe mild, moderate or severe [50]-[53]. Interestingly, though, because of the influence of television, $\mathrm{AD}$ is now part of the vocabulary of the elderly, which they associate with ulyanin. It signifies a change in understanding - from the idea that dementia is natural to aging to dementia as sakit sa utak (neurological disorder). This, however, has the effect of creating a dreaded identity of dependency about a sufferer from an incurable disease who places the burden of care on others.

Health relates to work as pastime or work ability. Attitudes toward work, though, differ. In industrialized countries, work after retirement is a choice [54], but in developing countries like the Philippines it is a necessity among poor elderly. Self-employment suits the elderly more than employment in the civil service or in the private sector. It requires little capital, and it is not subject to policies, rules, principles and practices that discriminate the elderly in terms of recruitment, training, employment and promotion [31]. It is thence likely for the self-employed to continue working for as long as they could. Gainful work contributes to a positive sense of well-being among the healthy and strong [55] because income, no matter how meager, "represents an improvement in individual well-being” ([54], p. 413).

The poor have to work to live. Remigio is 67 years old, and he still drives a motor cab for a living despite having suffered from a stroke. He complains about dizziness, weakness and shortness of breath, but he feels a sense of loss on days that he could not drive. Ariston, who is 70 years old, still vends green mangoes on the sidewalk, and the little money that he earns he gives to his wife Minda for their basic needs. Leonita, who is 72 year old, continues selling sweets made from rice in their neighborhood and other parts of the city because she is still strong and healthy, and her poor children depend on her. Since poor health can restrict strenuous activity, vending and peddling are congenial to the elderly, but not driving for health reasons. While men and women 
vend on the sidewalks, only women continue peddling sweets. Some of the women work at the center as cleaners and sweepers.

The women, mostly widows, want to work for cash, and they mention the cleaners and sweepers at the center as examples. They are aware, though, that any gainful work for the elderly pays so little. They try to dismiss this and emphasize, instead, what they gain from it, saying, "Di bale na; ang mahalaga kumikita ako. Malaking tulong din yan" (Never mind; what is important is I am earning. It helps a lot). Paid work "plays an important role in the relationship between generativity and successful aging", and it is "a predictor of aging well” ([44], p. 193). It lessens the dependence of the elderly on their children, it enables them to help needy children, and it provides them opportunities for social connectedness.

The elderly are a group unto themselves or, as Arsenia says, "kami-kami lang", to denote identity, solidarity and connectedness. They prefer same sex and same age-range friends, and they are loyal to one other. They visit each other, watch free movies together and hang out together. Moreover, Emilio says, "Damayan pag may nabawas sa amin" (We condole with one another when one of us dies). Friendship is reciprocal in nature, involving the exchange of mutual support [56]. Friends compose a network that provides social life for everyone [57]. This revises ageist views about the elderly as socially withdrawn, inactive, unproductive and prone to chronic diseases [38] [58]. The more connected to the "world" they are, the happier they turn out to be.

\subsection{Change and Agency}

Di tulad ng dati is a description of the changes that happen on the individual through the years. The skin wrinkles and sags, two changes due to aging that are easily perceptible on the self and on others [59]. The bone weakens and may cause chronic pains [60]. The gradual way these signs of aging manifest on the body help in fostering an accepting attitude toward aging as an inevitable natural phenomenon. Changes in appearance, though, are not as important as decreases in strength, proneness to disease, insufficient resource, social relationships, living arrangements, etc.

At 65 years old, Inocencia feels strong. She describes her capacity for IADLs in the following words, "Siempre, noong kabataan ko at wala pa akong naramdaman, one hundred per cent nagagampanan ko" (Of course, when I was young and did not feel anything wrong with my body, I was able to do them one hundred per cent). Activity, however, decreases with age and frailty [61]. Bernardita is 75-years old, she is frail, and she lives with her husband in their own house. She has difficulty doing strenuous chores, such as the laundry, which is one of the reasons why her daughter Maritza and family now live with her. She says, "Hindi ko na kaya ang sarili ko.Nahihirapan na akong umupo, kaya anak ko na ang naglalaba para sa akin" (I cannot care for myself anymore. I have difficulty sitting down, so my daughter (Maritza) does [the laundry] for me now).

Unpleasant feeling, such as fatigue, weakness and disease, are common complains. Kapaguran (fatigue) has a known cause: it is due to aging, and it is not a disease [62]. "Fatigue is one of the most common symptoms experienced by older people, with or without chronic disease. It is unpleasant and distressing and can affect functioning and quality of life" ([63], p. 1403). It pertains to frailty that denotes multiple physical deficits due to aging [64]. It can result to inactivity and social disconnectedness for a short time. The approaches against fatigue include avoidance of such strenuous activities as aerobics, ballroom dancing, long walks and long-distance travel on the one hand, and rest and sleep on the other hand. Rest and sleep at home for a few days are enough to reinvigorate the body, and it is back to active life again.

The body is either malusog, mahina or sakitin. Pananamlay (malaise), a sense of exhaustion that has no known cause, suggests the onset of disease. Sakit refers to two conditions: sakit, as pananakit (pain), due to fatigue; and sakit, as disease, due to various causes. Sakit, as disease, is infective or not, chronic or not, recurring like cough and colds, etc. Chronic diseases, such as arthritis, high blood pressure, stoke, cataract, diabetes, etc., can lead to inactivity for life [65]. Arthritis and rheumatism, cough and colds, indigestion, emphysema, poor eyesight, poor hearing, high blood and hypertension, kidney stones, gallstones, osteoporosis, etc., constitute a constellation of complains about an aging body. Some complains could be symptoms of disease: sore knees for arthritis or gout; poor eyesight for cataract; difficulty in urination for renal disorder; dizziness for high blood pressure; and hard cough for pneumonia or bronchitis. The onset of chronic disease signals aging, which makes sufferers accept that they are matanda na. Perfecta, who is 64 years old, states that aging makes the individual prone to disease, and she gives herself as an example by saying, "Hindi na ako palaging malusog. Matanda na" (I am not always healthy anymore. I am already old). 
Keeping the body healthy is a personal responsibility through activity, change in lifestyle and medication. These approaches obtain from the presumed links between lifestyle and disease based on experience and knowledge of disease and local cures. A healthy diet and active life can help prevent or control high blood pressure or diabetes. "Commitment to physical activity may help to reduce fatigue in overweight-to-obese" ([66], p. 144). Whenever she feels weak, Zenaida resorts to a local "cure" for diabetes to assuage her fears of the disease. She says, "Paminsanminsan para akong pagod. Ngayon, inuunahan ko na, siguro, kako, baka may ano ako [diabetes], so I drink amplaya" (Sometimes I feel tired. I suspect that I have diabetes, so I drink amplaya [bitter gourd] to prevent its onset). Her behavior is not unique because self-medication is common among sufferers of chronic diseases around the world [67].

Health-seeking practices differ. The affluent and less poor see the doctor and buy medicines that the doctor prescribes, they can afford surgeries, and they take multivitamins. The poor self-medicate based on their experience and by asking friends for advice. They take analgesics for headaches, anti-motility drugs for diarrhea, mucolytics for dry cough, etc. They see a doctor should their resources make it possible. Because they cannot afford surgeries, those with cataracts go blind, the arthritic stay at home, and those with goiter die without relief from difficulty of swallowing food. Depending on their networks, some are able to address their problems by asking influential people for help. Timotea wears a hearing aid that the Philippine Charity Sweepstakes provided her. Poverty makes them value health. Yolanda stresses the importance of health over resource by telling her children that, "Kahit wala tayong pera basta wala tayong sakit" (Never mind that we are poor, what is important is we are healthy). Eleuteria expresses the same views, saying, "Tama na sa akin ito... kahit hindi ako mayaman basta healthy" (I am satisfied with my life... [I do not mind] that I am not rich, what is important is I am healthy).

Resource includes pension, inheritance, business, paid work and support from children. Widows, former housekeepers and never married women who have no pensions are poor [68]. The never married women, however, are the poorest because they have no children to care for them in late life. However, the gap between the pensioners and the non-pensioners is not wide because of "pensioner poverty" ([69], p. 1).

Most of the males are pensioners of the Social Security System (SSS) or of the Government Social Insurance System (GSIS). There are few female pensioners because few used to work. One was a gift wrapper in a department store, and another a public school teacher. Regardless of gender, health and economic means, the pensioners do not show interest with work for different reasons. They associate retirement with pahinga (rest), and they try to survive based on their meagre pensions, with or without the help of their children. They consider themselves physically unfit for the jobs that they used to do, and mental jobs that suit their experience and age do not exist. Disinterest with work can be an influence of ageist images of retirees as living comfortably and happy.

This contrasts with the attitude of some widows who want to work. Their positive attitude toward work is an effect of freedom from reproductive and childrearing roles. Carlota, a cleaner at the center, receives a monthly allowance of 1500.00 pesos for the job. Each time that she receives her allowance, she wants to go shopping. Her daughter Kulasa, says "Aba feeling nya mayaman sya dun sa kanyang natatangap. Yun and kasiyahan nya dito" (She feels rich because of what she receives [from the center every month]. It is the reason why she likes it here). She has no paid work history before widowhood. She regards aging as a state in life when she can pursue things that she did not have the time to do as parent and spouse. Aging then creates new possibilities depending on the individual's health, interest with work and the existence of paid work.

As they grow old, individuals make adjustments in their interpersonal relationships toward connectedness with others [1]. The need for connectedness becomes more important upon retirement and widowhood. "[T]he association between disconnectedness and mental health may operate through the strong relationship between perceived isolation and mental health” ([43], p. 31). Wenger et al. ([70], p. 333) make a distinction between isolation and loneliness: thus, "The critical factors for isolation are: marital status, network type and social class; and, for loneliness: network type, household composition and health”. Widows and widowers are more isolated than those with spouses, social disconnectedness increases with years of widowhood, and the lower classes are more isolated than the upper classes because of limited activity due to poverty. Membership in organizations, co-residence, health and positive attitude toward life militate against isolation and loneliness. Connectedness plays out in the family, kinship, friendship, membership in organizations and volunteerism.

Kinship, as "super family" ([71], p. 7), is organized "on the basis of common descent" ([72], p. 3) and is obligatory in nature [57]. However, beyond the third generation, it may not play a significant role in urban life be- 
cause of migration, distance and poverty. Relatives who migrate to the city live apart from one another because of work and poverty that prevent them from seeing and helping one another. Because of weak kinship ties in the city, the idea of kinship centers on the household, which, like the nuclear family, is also a pre-Spanish social form in the Philippines [73] [74].

The Filipino kinship structure is bilineal, while the family structure is nuclear in some groups [73] [74] and extended in others [75] [76]. Co-residence, however, unsettles the stability of the nuclear family. The nuclear family becomes a household or an extended family when a child accommodates a widowed parent in his household or when an elderly couple welcome to their home a poor son and family. Co-residence befuddles some writers, though. The observation that, "The majority of the Filipino households today remain nuclear in composition; however, they are also functionally extended... In recent years there has been a fast decline in the household size in the Philippines as well” ([77], pp. 62-63), manifests this. It results from the predisposition to elide on ethnic heterogeneity and the failure to consider the effects of aging on the nuclear family.

The family is a social resource that contributes positively to a better sense of life [1]. Familial relationships are important because they are "rooted in blood relationships, that these are the fundamental social ties" ([72], p. 3). In less than ideal situations, the family can be a stressor [42]. Manding, a widow and pensioner, complains about a jobless and drunk son who, together with his family, lives with her. She tries to cope with the situation by leaving the house after breakfast and spending the rest of the day with her friends at the center. "Masaya ko dito, walang sakit sa ulo" (I am happy here; I do not feel stressed out here), she says.

Since the family remains the site of care [78], living arrangement in late life involves two options-independent residence or co-residence. There are three modes of independent residence: living with a caregiver; living with spouse; and living with a relative. In the strictest sense, independent residence is not living alone; rather, it is living in one's own house, with company, separately from the children. Those who choose to live independently from their children are homeowners [79]. This underlines the importance of property in making decisions about living arrangements and making choices about one's life day after day. Lucia is an 84-year old affluent widow who lives with a caregiver in her own house and away from her children. Her children provide for her based on income from her estate that include apartments and a restaurant [42]. Eleuteria and her husband are government pensioners who live in the house that their children bought them. The children also provide them a house help for assistance around the house and doing errands for them. Dolores lives in her own house, together with Emily, a granddaughter by her daughter Soledad who lives in the province. She and Emily manage to survive on the small amount that she receives from a family that rents one of the rooms in the house.

Co-residence is the common mode of residence among the poor. There are two modes of co-residence: for homeowners, living in one's house with one or more of the children; and for non-homeowners, living in the house of one of their children [80]. Spouses live in their own houses with their children, while widows and widowers live in the houses of their children [81]. Heliconia and husband Benjamin used to live in their own house, with two married children. However, the children bickered over such basic expenses as electricity and water bills, and, in the end, they decided to live apart from each other and leave their parents behind. Maritza, one of the daughters of Heliconia and Benjamin, decided to move to her parents' house so that she can take care of them.

Conventionally, the children who live with their parents are the youngest or the poor child. If female, she justifies the role on the idea that caring is a woman's role. Parents may take in a poor child. A married son of Eleuteria, who used to work abroad, lives in what used to be the garage of the house. A poor child takes in a widowed mother or father in his household, while a "rich" sibling, usually unmarried and working abroad as a nurse or seafarer, sends support for the parent/s and the household.

Co-residence is a cost-efficient way of raising a household. The relationship between parents and children can be reciprocal in nature [82]. Arguments for the reciprocal nature of co-residence emphasize its short-term benefits, such as the elderly sharing shelter, food, etc., with the rest of the household in exchange for childrearing roles. "In cross-generational family, the role and value of caregiving for grandchildren by elderly grandparents has been strengthened, as has the burden of care placed upon them” ([78], p. 58). The long-term benefits are cultural: the elderly teach the young elements of culture that are critical to survival [8] [9].

Reciprocity in co-residence, though, can be unequal. It happens that the resources of the elderly are also those of the household. It is common for pensioners helping in the expenses for food and the electricity and water bills. They are always in debt because they borrow money from lending agencies or usurers in order to help pay the bills. Juanita lives with her daughter, and she reserves the pension of her deceased husband for the bills. She 
says, “Minsan kapos kasi tumutulong ako sa anak kong babae. Sagot ko pambayad ng kuryente” (Sometimes it [pension] is not enough because I help my daughter. I am responsible for the electricity bill). The strong and healthy elderly do housekeeping roles that include going to the market and preparing food for the entire household. Perfecta expresses her sense of confusion and annoyance about the set-up. She says, "Minsan naguguluhan din ako kasi ako ang in-charge sa pagluluto, pamamalengke... Minsan nayayamot din ako dahil ako lang inaasahan” (Sometimes I am confused because I am in-charge of cooking, going to the market... I am sometimes annoyed because they all rely only on me). These experiences are by no means peculiar because, "Older adults around the world provide care and support for their family, relatives, and friends” ([78], p. 58).

The reasons for co-residence differ. The elderly rationalize it on sama-sama (togetherness) to affirm the family as the site and actor of care for the elderly. Co-residence helps ease anxieties due to aging, such as the need for belonging and connectedness with loved ones and care from the children. In the words of Heliconia, the elderly need their children "dahilmatanda na o di kaya mahina at may sakit” (because they are already old or weak and sickly). Leodivina has three sons, two unmarried and living with her and husband, and one married with children, who now lives with them also. She likes it this way so that the children can help look after their sickly father. She says, "E, gusto ko may kasama ang tatay nila sa bahay kasi anytime na [may mangyari sa tatay nila na may sakit] may kasama sya. Pumapasok kasi ang dalawang anak namin na nakapisan sa amin” (I want their father to have company always so that anytime [that something bad happens to him] he has company. Our two sons who live with us go to work). Co-residence of this type is common in the Philippines [83].

The children premise co-residence on filial piety, the "breeding of children for oneself” ([84], p. 209). Traphagan ([34], p. 93) shows that in countries like Japan, where the eldest child, usually a son, inherits the property of the parents, the parents can "legitimately expect to depend upon at least one child for solid support in old age”. Filial piety, utang na loob in Tagalog [85] [86] or utang kabubut-on in Bisaya [87], is a strong value, "rooted in the reciprocal arrangement of reward qua gratitude" [88] (p: 160). It works in conjunction with gaba (fear of retribution) and/or sense or hiya (shame) for regening on obligation [88]. However, premising care for the elderly on utang na loob (reciprocal obligation) can be overblown because children change over time and renege on utang na loob.

Reneging on utang na loob partly explains the situation of Dolores: none of her three children cares for her. She explains this away by saying, "Malalayo sila, yong isa sa Laguna, meron sa Bikol, at mas mahirap pa sila sa akin" (They live away from me, one of them is in Laguna, another lives in Bikol, and they are poorer than me). In a way, this sustains the view that the economic status of children is a critical factor to care for the elderly [83]. However, it happens always that when one child reneges on utang na loob, another steps up for the role no matter the cost for reasons more weighty than economic means. The situation of Heliconia and Benjamin needs mention. She says, "Kaya nga umuwi sila sa amin, e, kasi yung dalawa kong anak na may pamilya wala na, e, hindi na rin sila maasahan, e. Bale sya na lang nag-aano sa amin” (They [Maritza and family] decided to go home to us because my two other children left us, and we cannot rely on them anymore. So she is the only one who cares for us). A situation like this "suggests a transition from relationships based upon obligation to those voluntarily assumed and maintained by aged parents and their adult offspring” ([89], p. 303).

Besides the household, friendship is also an important site for social bonding. Grounded on notions of bigayan (mutual giving), it involves the exchange of support that is more social than economic [56]. Usually composed of same sex and same age-range individuals, it answers to the need for connectedness between nonrelatives. It becomes more important when familial relationships are disharmonious. A drunk, jobless son, a selfish daughter-in-law and bickering children can make an elderly find solace in friendship. Friendships "promote well-being in old age” ([57], p. 266). Neighbors, though, do not always make good friends for dissimilar motives. Leonita refuses to make friends with neighbors because she does not like rowdy males when drunk and women who engage in petty talk and rumor mongering. Zenaida ignores her neighbors because she is shy, and she prefers to stay at home and keep herself busy with chores.

The center for senior citizens is a beehive of activity based on friendship. Its location on one side of Marikina River makes it a preferred place to spend daytime away from home. It hires some of the elderly as cleaners and sweepers, and it sells the bags and purses that the women make from plastic beads. It is spacious, it offers activities for fitness and health, it provides information that concern senior citizens, and it is accessible by public transportation. There are sheds, tables and benches, and there is running water too for cookouts. The sense of activity, acceptance, belongingness and commensality makes the center the place where old friends meet and new friendships form. 
Friendship contributes to satisfaction in life. Siebert et al. point out that, "commitment to the role of friend is significant in predicting life satisfaction..., friendship identity meanings emerged as the strongest predictor-stronger than income and marital status—-when predicting well-being” ([90], p. 252). Eleuteria affirms this, saying, "Masaya ako dahil una sa lahat kay Lord, sa mga anak ko at sa mga kaibigan ko" (I am happy because, first of all, the Lord, my children and my friends). Individuals benefit from the "support and friendship [they] offer each other through their commonalities, activities, and sense of humor” ([91], p. 46). Friendship forms the core of the social network in late life. Widows and widowers have smaller networks than those with spouses because of "familist" values, such as close family ties [92], choice and poor social skills. Unlike kinship where relationships are compulsory, friendship is voluntary in nature. Individuals choose their friends, including ending relationships that only vex them, freely: "older adults cease emotionally detrimental relationships" ([57], p. 266).

Organizations are important sites of social network building, involvement and activity. They are religious or civic, and membership is either inactive or active. Active membership is "quite common" [93] (p: 188) in the elderly. In the World Values Survey [94] data set for 2005-2006, "active membership" or "unpaid work for the organization" pertains to volunteer work. Volunteerism is common among 65 years old and older women because they are now free from childbearing and childrearing roles, and the free time that they have they spend on volunteer work. Volunteerism relates to well-being. "It needs to be remembered that older people's opportunities of belonging through membership and their contributions as volunteers are significant in terms of individual health and well-being” ([93], p. 188).

Marita, an active deacon of the Iglesia ni Kristo, meets with other deacons every week for church-related work-proselytizing on non-coreligionists. She complains of fatigue and body pains when she arrives home, but she never stops from trying to fulfill her obligations as a deacon every weekend. Leveriza, a Catholic, is an active member of a prayer group in her neighborhood. The members of the group call each other "sister" or "brother". They do not only meet on Sundays but also on other days of the week because of the satisfaction that they derive from a life of prayer and the sense of belonging that the group provides. The "sisters" are busy church members, attending mass and joining prayer meetings. They celebrate fiestas and organize pilgrimages to local shrines during Lent. In addition to these, Eleuteria is happy to share that she is an active member of the homeowner's association of the village in which they live.

Some of the elderly donate plastic bottles and other recyclable materials to the Tzu Chi Foundation. Tzu Chi, as the elderly call the foundation, is a Chinese organization committed to protecting the environment through garbage segregation and recycling toward "A Clean Earth" [95]. It mobilizes volunteers, including the victims of floods and the elderly, for relief work as happened in Marikina when typhoon Ondoy (international codename Ketsana) struck the city in 2009. Opportunity and environment for paid work and volunteerism [41] make the elderly productive members of society who can help themselves as well as others.

Volunteerism answers to the need for social connectedness that increases with widowhood. "This suggests that continuity of volunteer engagement and enhanced social participation are important following widowhood" [96] (p: 158). Like friendship, it challenges notions about the elderly as socially disconnected individuals. This is consistent with the view that "some later life transitions, such as retirement and bereavement, may prompt greater connectedness" ([41], p. 185). Furthermore, as individuals occupying positions of power, widows are effective in "bridging", in making people connected with one another, than retirees and the sickly do [97].

Friendship, membership in organizations, paid work and volunteerism attest to agency in aging. Agency refers to autonomy, independence or control that the individual has over his life. "One aspect of autonomy is the right of the individual to control his or her own life" ([98], p. S5). Autonomy is cognitive: it pertains to the capacity to make independent decisions, including making choices for preferred health care. A non-dementing elderly can decide by himself and act on his decision. It is in this connection that the story of Lucia needs repeating in a different light. She is normal, but her children now control her estate after acquiring from a lawyer the power to do so on the ground that she is ulyanin. She calls her businesses laruan (toys) to denote how managing her estate provides her activity and leisure. Autonomy is also economic, and it entails not only providing for one's self but also exercising control over one's resources. Lucia is ambivalent toward her children: she is grateful for the support, but she is sad over the loss of control over her estate. Her situation shows how those around the elderly can use ageist stereotypes about dementia in order to redefine their existence.

Complains about insufficient resource are common. However, satisfaction in life is independent from economic autonomy, which explains why most of the elderly claim that they are happy despite their poverty. Happiness is an attitude toward life, a personal commitment and based on the past. Zenaida states something axi- 
omatic about happiness. She talks about what makes her sad and anxious, not what makes her happy. The past only makes her sad, and the future worries her. She says, “May oras na masaya, may oras na malungkot... E, minsan, naalala mo yung naging buhay mo, lalong inuunahan ko. Yong sa darating na panahon, yon ang lagi kong iniisip." (There are happy times, and there are sad times... Sometimes you remember your past life [that makes you only sad], so I try to cope with it. I think about the future). She feels responsible for herself, and she tries to cope with her anxieties by not thinking that she is sick, entertaining herself, keeping herself busy with chores and visiting her son when she could. She says, "Iniiwasan ko mag-isip na my sakit ako. Nililibang ang sarili, mag-isa pumunta sa mall, minsan pumupunta ako sa anak ko, malayo, sa bukid. Kilos ng kilos, hindi ako naglalabas, bihira akong makipagkwentuhan... kasi mahiyain ako” (I avoid thinking that I am sick. I entertain myself, I go to the mall alone, sometimes I visit my [son]. He lives far from here; it is in the mountains. I keep myself busy [at home]. I do not go out, and I seldom talk with other people because I am shy).

Health and longevity, sociality and activity, resource, etc., are important but they do not determine happiness. Contrary to the idea that associates "successful aging” with "healthy life expectancy" ([99], p. 6), the poor and sufferers of chronic diseases could claim happiness as the less poor and healthy do. Happiness is a personal responsibility, and normal individuals try to be happy no matter their status in life. One thing is clear though: "There is a sociality to happiness" ([42], p. 21), which is about sharing one's life with others. Everyone tries to visit friends. The men see each other to drink and watch their boxing and wrestling shows on television. The women organize trips to fiestas and pilgrimages to their patron saints during Lent. It helps that the center provides some games and fitness activities. The women go to the center to work, make purses and bags made of plastic beads, play cards, join in dance sessions, cook out with friends or simply talk with friends and pass the daytime away. The men play ground golf and chess, exercise, chat or join the women in cookouts. On Mondays and Tuesdays, they go to the theaters to watch free movies and meet with their friends too.

\subsection{By the Grace of God: Sa Awang Dios}

Aging creates new opportunities for the elderly to pursue hobbies, maintain a social life, have fun and give more time to spiritual life. Belief, religion or spirituality refers to the idea of the supernatural, which, in Christianity, refers to God. It also refers to "a type of experience which allows one to see the difference that God makes to mere experience” ([100], p. 16). Religious experience "brings us into relation with a felt power that assesses what we are and have attained” ([100], pp. 3-4). Ferris [101] posits that belief in the hereafter contributes to a positive sense of well-being, while Idler [102] argues for involvement in activity, and Hadaway [103] insists on commitment. Activity includes rituals [104], which, in Philippine contexts, pertains to prayer meeting, attending mass, going to pilgrimages [105] and fiestas [106], Lent [107] [108], Christmas and New Year, Papal visit, etc. Except for a few who are members of the Iglesia ni Kristo, most of the elderly are Catholics. Regardless of religion, they commit themselves to their beliefs, which contribute toward positive mental health and social life [109].

Belief in the hereafter does not occur in the data, which implies that it is not as important as the other aspects of religious life. Instead, the data attest to the importance of belief in an all-powerful God, activity and commitment. There are activities that the elderly feel obliged to perform. Marita meets with fellow deacons of the Iglesia ni Kristo for church-related work on weekends. Catholic women attend mass on Sundays, and those active in volunteer work in the parish attend prayer meetings. Leveriza and her "sisters" pray together on Saturday nights and on other days of the week. Fiestas are a source of fun and piety [106]. Some Catholic women have panata (devotions) to saints, and they try their best to fulfill the panata by going on pilgrimage to the shrines of the saints [110]. The panata is part of their reciprocal relationship with saints who, they believe, intercede for them before God in heaven. Widows are active in these religious activities, suggesting the links between aging and religious activity [41].

The elderly narrate their religious experience more than they do anything. They try to comprehend experience through linguistic representations that convey its "physical, mental, and emotional constituents” ([100], p. 17). Religious experience is episodic, anticipatory and private. The episodic can be something “exciting”, "tumultuous” ([100], p. 4) or simply those relating to such mundane concerns as health, security, the welfare of the children, longevity and life itself.

Mercedita links disease with aging. "Lahat tayo tumatanda, nagkakasakit” (We all grow old, we get sick), she says. She adds, "Mabuti pag walang sakit” (It is good to be healthy). Her husband Pablito suffers from emphy- 
sema because he used to smoke. She hopes that his condition would not worsen, saying, "Sa awa ng Dios, sana di umabot sa ganon" (By the grace of God, I hope that it would not worsen). Perfecta believes that the elderly are prone to disease. She says, "Madaling maano rin magkasakit pag matanda na” (The elderly get sick easily). She also makes a connection between disease and poverty, which is revealing, saying, "Nakakahiya kasi mahirap lang ang palaging inuubo at sinisipon" (It is embarrassing because only the poor get cough and colds always). She attributes her health to God, saying, "Sa awa ng Diyos naman, miski payat. Di ako sakitin" (By the grace of God, I am thin but I am not sickly).

Health concerns include surgeries and successful recovery. A few of the elderly undergo surgeries for cataracts, kidney stones or another diseases. Eleuteria recalls that she had difficulty sleeping after her surgery for kidney stones because of the itchiness that she felt all over her body. She prayed to God for relief from itchiness so that she can sleep. Two weeks after, the itchiness was gone and she was able to sleep. She says, "Sa awa ng Dios, mga two weeks na after my operation, nakakatulog na ako nawala ng pangangati” (By the grace of God, it was about two weeks after the operation that I was able to sleep because the itchiness was gone).

Family members fear that something bad could happen to the elderly on the bus, train or on the streets. Although this pertains more to the frail elderly than to the strong ones, they ensure that the elderly has company when they leave the house and go somewhere that involves crossing the street or taking a public transportation. They also fear that the elderly would wander and lose their way. How Mercedita and family care for Pablito illustrates these concerns. She says, "Sa awa ng diyos naman, nakakapadbyahe mag-isa, kaya lang hindi namin pinapayagan, kailangan may maghatid sundo" (By the grace of God, he can still travel alone, but we do not let him do it anymore because he needs someone to bring him to where he wants to go and take him home too).

Economic status is an effect of education and job history in midlife [31]. This is to say that those who had little or no job history while still young would be poor in late life, and that their children would be poor as well. It is the case with the poor elderly, who feel guilty for the poverty of their children,and theyfeel responsible for them. They consider part of lifetime parenting roles such gestures as taking a poor son and family into their home and helping him in every way they could to ease his difficulties. The poverty of the children is cause for sadness and helping them is joy. Beyond this, they say, "Wala na tayongmagagawa” (We can do no more). A government pensioner like Eleuteria, though, is satisfied with the status of her children because they are professionals and working. She thanks God for this, saying, "Sa awa ng Dios, ang mga anak ko, e, napatapos ko lahat sa kabila ng hirap ng buhay... Professionals lahat sila” (By the grace of God, I was able to make my children finish school despite the hardships... They are all professionals).

Eleuteria suffers from chronic diseases. She has diabetes, hypertension and allergic rhinitis that trouble her a lot. She also had a successful surgery for kidney stones. She considers herself blessed despite her condition, and she attributes her longevity, health and strength to the kindness of God. Zenaida feels and thinks the same way. She says, "Sa awa ng Dios umabot ako sa ganitong edad at malusog at malakas pa sa kabila ng diabetes at hypertension" (By the grace of God, I reached this age, and I am still healthy and strong despite diabetes and hypertension).

Longevity provides an opportunity for the individual to ponder life and mortality. Everyone dies but the idea that the time of death is unknown creates unpleasant feelings. Leveriza reflects on her life and thanks God for it. She says, “Nababahala ka minsan. Pagka kami nga nagprayer dito, nagiiyakan yung mga kaibigan ko kasi dinadaing ko kay Lord hanggang kalian pa ako bukas, mamaya? Eh, kako, eh, ang lakilaki naman ng bonus Lord. Pwede mo na ako kunin ngayon" (You are sometimes anxious. When we gather to pray here [center for senior citizens], my friends cry because I ask the Lord when he would take me, would it be tomorrow or now? I say, Lord, [the long life that you give me] is a big bonus. You can take me now). She is conflicted toward life: she is happy for longevity, but she is sad and tired of taking maintenance medicines. She says, "Mamaya, bukas yung mga kaibigan ko, yan maglalapitan sila. Sasabihin nila, 'Ang sarap ng buhay, sister'. Sabi ko sa kanila, 'Oo, alam ko yon, kaya lang parang pagod na pagod na ako.' Isipin mo naman, forty-eight hears old pa lang ako nag-iinom na ako ng gamot" (Now or tomorrow my friends will see me. They tell me, "Life is beautiful, sister". I tell them, “Yes, I know it, but I feel very tired.” You come to think of it, I was only forty-eight years old when I started taking medicines [for hypertension]).

Sa awa ng Dios articulates a world view. It enables the individual to deal with his humanity that involves recognizing his mortality and at the same time making his vision of himself in his world real. In the words of Gaudencio, “Ang buhay ay dapat nating mahalin, kaloob yan ni Lord” (We should love life, it is God’s grace), which sums up his belief about life as God's grace. Belief contributes to a positive sense of life. Eleuteria says, 
emphatically and assuredly, “Talagang satisfied ako. Una kay Lord, sa pamilya ko, sa mga kaibigan ko” (I am really satisfied with my life. I owe it first to the Lord, to my family, to my friends). The belief that health, including successful surgeries, the safety of loved ones, the success of the children in life, support from the children, long life and life itself become possible because of a God who is gracious to all those who seek Him.

\section{Discussion}

The elderly are a diverse population, thus talk of aging elicits different responses. The frail and sufferers of chronic disease associate aging with decrements in strength and productivity, proneness to disease, especially chronic ones, smaller social networks, etc. [30]. It obtains from keenly observing the body and the changes that it undergoes across the life course rather than an effect of ageist discourse as some posit [37] [38] [111]. The healthy and strong resist it, which resistance finds resonance in the concept of "ageless self” [29]. The "ageless self”, though, plays into such concepts as ableism, active aging, productive aging and successful aging that cast the frail in miserable light. In a sense, the homogeneous images of the elderly that these concepts create are as ablest as they are ageist [5].

Keeping the body healthy and active is a personal responsibility and a lifetime commitment that involves keenly observing the body as an organic entity. The awareness that aging is a transformation from "youth” to "elder" [9] obtains from this process. The elderly use idioms to describe the condition of the body, and they act upon the body based on the meanings of the idioms. For instance, they understand dementia as ulyanin, and they associate feebleness with dementia not aging. Keeping a robust body is an intricate practice that includes making connections between health, disease and activity. The idea that an active body is healthy arises from this, including the impulse for self-medication in the hope of relief from or cure of chronic diseases among sufferers. The tendency to naturalize activity as a bodily response against disease [112] flattens difference by assuming that the elderly are a homogeneous population of healthy, strong and active individuals. It separates the sick and the frail from the healthy and strong, which runs the risk of stigmatizing them as aging negatively, unproductively and unsuccessfully. Studies show that activity decreases with age no matter the will and health of the individual [35].

Living independently from children is the ideal set-up in late life, alone or with spouses and regardless of economic condition as long as possible. Longevity, poverty, frailty, choice and family values transform the nuclear family into a household because "larger households [are] more likely to be caring for an extended family member” ([113], p. 357). This is in contrast to the unfounded view that modernity leads to smaller families (Go, 1994). The three- to four-generational household provides a sense of integration that becomes more important in late life because of loneliness due to poor health, isolation from loved ones and widowhood ([114]. In contrast, ethnohistorical [73] and ethnographic [74] evidence show that in cultures where the nuclear family is the rule, the poor elderly live alone, too old to fend and care for themselves, and they die malnourished and abandoned by their children.

Living alone is a predictor of hardship among poor elderly [69]. The widows and widowers and the never married women, including the sick and frail, prefer co-residence. "Co-residence is considered as an important form of support in its own right, and, as we have seen, often conditions the other forms of support” ([83], pp. 25-26). However, the set-up has had the effect of making the elderly dependent on their children, which contrasts with an identity for autonomy that many elderly assert by living on their own. Views about the short-term reciprocal benefits of co-residence [113] need to change so as not to lose sight of the strategic importance of childrearing to the reproduction of aspects of culture that enhances the survival of the young in the descendant generation. Attention should shift from looking into the benefits that the elderly receive to the contributions that they make to the household. The pensioners and those who still earn for a living contribute as much as productive adults do to the well-being of the household.

It is a truism that a culture that encourages aging produces elderly populations in society. However, the idea that a culture that promotes filial piety in the young produces filiation among them needs reconsideration. How utang na loob operates, alone or in relation to gaba and hiya, is still poorly understood and needs to be examined further [80]. One needs to look into the role of consciousness of filial piety and volunteerism, the economic status of the children, the decision-making involved and how filial piety and voluntarism prevent depression that caregivers for frail elderly suffer [113] in order to understand more deeply how debt of gratitude plays out in care for the elderly. 
Friendship, membership in organizations, volunteerism and paid work are independent from familial relations. They are important aspects of sociality that contribute to satisfaction in life. Friendship remains the core relationship, and it serves as an anchor to other modes of connectedness and social network building. Volunteerism remain constant even upon widowhood, while poor, healthy and active widows show interest in paid work that suits their abilities. It would be interesting to look into the positive effects of widowhood in relation to sense of freedom and interest with paid work.

Belief in God, immortality and in good and evil does not seem as important as activity and commitment in fostering a sense of community and integration with co-religionists. Belief in a gracious God intensifies with crises. Life itself is a manifestation of the experience of a gracious God. The less poor are more candid about their belief than the poor: they owe everything to God-longevity, health, the success of children, etc. If one's status is an attestation to God's grace, then the poor have less to declare about this, which is not to say that they are less satisfied with life or are less religious. Rather, belief is not something that they resort to even in difficult times [103]. Besides, other indicators, such as the role of doctrine and membership in church organizations, may play vital roles in the religious life of individuals.

\section{Conclusions}

The elderly communicate in idioms to convey their feelings and thoughts about their experience of aging to others [23] [24]. The idioms serve as frames, the conventional ways of saying something [25], and as building blocks of ideas upon which they build a universe of meanings as they try to make sense of the changes in identity that result from growing old. However, because they are a diverse population and since aging is a complex and dynamic process, talk of aging encourages a cascade of responses that maybe coherent, ambivalent, conflicting or ambiguous in meaning. Nonetheless, two ways of thinking about aging emerge: the idiom tulad $n g$ dati, as kabataan, bata pa, malakas pa, kaya pa and malusog, amplify aging as a continuous process, [2] [29] [33]; and di tulad ng dati, as katandaan, matanda na, mahina, di na kaya and sakitin, articulate aging as a discontinuous process [36].

Tulad ng dati plays into the concept of "ageless self" [29]. It is, however, ambivalent in that it is conscious of aging as a life changing process and at the same time interrogates ageist stereotypes that portray aging as a stage in life characterized by gradual wasting in physical and mental prowess, social isolation, disease, and inactivity [30]. It calls into question assumptions about the elderly as a homogeneous population, and redirects attention to the elderly as heterogeneous as any other age-based group [37] [38]. It suggests what the elderly are capable of and consider important, such as health, activity and autonomy [42], which represents a sense of continuity in social values no matter what those around them think.

Di tulad ng dati regards the life course as a process that involves transformations from "early" to "later" stage [4], from "youth" to "elder" [9], which is characterized by decreases in mental and physical prowess but not feebleness. It implies a consciousness that the elderly are no longer in their youth, and not an influence of ageist stereotypes as occurs in literatures [39] [37] [38]. Aging does not always connote decrepitude because, on the contrary, it can be creative, productive, liberating, and empowering. Without feeding into ageist and ableist ideas [5] [99] [112], it attests to new possibilities that included income, friendship, volunteerism, leisure and spirituality.

The relationship between spirituality, religion or belief and aging maybe viewed in three ways—as something that makes the individual happy, as compensation for suffering and as resource [115]. Growing old and happy can be "a result of ideology which expresses an optimistic view of life ([103], p. 41), a compensation for sufferings [116], while to others "religion is not something that persons tend to seek out in reaction to their misery" ([103], p. 641). Unlike other idioms that describe everyday acts, sa awa $n g$ Dios expresses mental states [24] about an experience that is familiar, but not quite because of the belief in the difference that God makes [23] [100].

\section{Acknowledgements}

R.C.E. thanks the following: the Philippine Council for Health Research and Development of the Department of Science and Technology for the grant that made the research possible in 2012-2013; the St. Luke's Medical Center-Quezon City (SLMC) for issuing the ethics clearance; the SLMC Research and Biotechnology Division where he was affiliated as anthropologist and assigned at the Memory Center of the Institute of Neurosciences 
during the duration of the research; the research participants; and the head and staff of the Center for Senior Citizens of Marikina City.

\section{References}

[1] Birren, J.E. (1958) Aging and Psychological Adjustment. Review of Educational Research, 28, 475-490. http://www.jstor.org/stable/1168974 http://dx.doi.org/10.2307/1168974

[2] Kaufman, S. (1981) Cultural Components of Identity in Old Age: A Case Study. Ethos, 9, 51-87. http://www.jstor.org/stable/640088 http://dx.doi.org/10.1525/eth.1981.9.1.02a00050

[3] Gems, D. (2003) Is More Life Always Better? The New Biology of Aging and the Meaning of Life. The Hastings Center Report, 33, 31-39. http://philpapers.org/rec/GEMIML http://dx.doi.org/10.2307/3528378

[4] Miguel, P.A. (2005) Evolution of Consciousness and Evolution of Life. MLN, 120, 1156-1167. http://muse.jhu.edu/journals/mln/summary/v120/120.5miquel http://dx.doi.org/10.1353/mln.2006.0019

[5] McHugh, K.E. (2000) The "Ageless Self"? Emplacement of Identities in Sun Belt Retirement Communities. Journal of Aging Studies, 14, 103-115. http://www.sciencedirect.com/science/article/pii/S0890406500800183?np=y http://dx.doi.org/10.1016/S0890-4065(00)80018-3

[6] McPherson, B.D. (1990) Aging as a Social Process: An Introduction to Individual and Population Aging. Butterworths, Toronto.

[7] Hirshorn, B.A. (1991) Introducing the Demography of Aging: Relating Population Processes to the Aging Society. Teaching Sociology, 19, 231-236. http://dx.doi.org/10.2307/1317855

[8] Katz, S.H. (1978) Anthropological Perspectives on Aging. Annals of the American Academy of Political and Social Science, 438, 1-12. http://www.jstor.org/stable/pdf/1042821.pdf?acceptTC=true http://dx.doi.org/10.1177/000271627843800102

[9] Robertson, A.F. (1996) The Development of Meaning: Ontogeny and Culture. The Journal of the Royal Anthropological Institute, 2, 591-610. http://dx.doi.org/10.2307/3034298

[10] Ingold, T. (2006) Becoming Persons: Consciousness and Sociality in Human Evolution. In: Moore, H. and Sanders, T., Eds., Anthropology in Theory: Issues in Epistemology, Blackwell Publishing, Malden, 180-192.

[11] Uhlenberg, P. (1992) Population Aging and Social Policy. Annual Review of Sociology, 18, 449-474. http://www.jstor.org/stable/2083462 http://dx.doi.org/10.1146/annurev.so.18.080192.002313

[12] Kirk, D. (1996) Demographic Transition Theory. Population Studies, 50, 361-387. http://www.ncbi.nlm.nih.gov/pubmed/11618374 http://dx.doi.org/10.1080/0032472031000149536

[13] Coale, A.J. (1984) The Demographic Transition. The Pakistan Development Review, 23, 531-552. http://www.jstor.org/stable/pdf/41259339

[14] Zhao, Z.W. (1996) The Demographic Transition in Victorian England and Changes in English Kinship Networks. Continuity and Change, 11, 243-273. http://dx.doi.org/10.1017/S0268416000003337

[15] Davis, K. (1945) The World Demographic Transition. Annals of the American Academy of Political and Social Sciences, 237, 1-11. http://www.jstor.org/stable/1025490 http://dx.doi.org/10.1177/000271624523700102

[16] Mosk, C. (1978) Demographic Transition in Japan, 1920-1960. The Journal of Economic History, 37, 655-674. http://dx.doi.org/10.1017/S0022050700095425

[17] Tiglao, T. and Cruz, W. (1975) Seven Decades of Public Health in the Philippines, 1898-1872. Southeast Asia Medical Information Center, Tokyo.

[18] Bongaarts, J. and Bulatao, R.A. (1999) Completing the Demographic Transition. Population and Development Review, 25, 515-529. http://www.jstor.org/stable/172345 http://dx.doi.org/10.1111/j.1728-4457.1999.00515.x

[19] Lee, J. (2010) Data Sets on Pensions and Health: Data Collection and Sharing for Policy Design. International Social Security Review, 63, 197-222. http://www.rand.org/pubs/working_papers/WR814.html http://dx.doi.org/10.1111/j.1468-246X.2010.01375.x 
[20] Kim, K. and Lee, Y. (2008) Comparative Analysis of Strategies for an Ageing Society, with Special Reference to Pension and Employment Policies. International Journal of Social Welfare, 17, 225-235.

http://dx.doi.org/10.1111/j.1468-2397.2007.00525.x

[21] Liang, Y. and Lu, P. (2014) Medical Insurance Policy Organized by Chinese Government and the Equity Health Problems of the Elderly: Longitudinal Comparison Based on Effect of New Cooperative Medical Scheme on Health of Rural Elderly in 22 Provinces and Cities. International Journal for Equity in Health, 13, 37.

http://www.equityhealthj.com/content/13/1/37

http://dx.doi.org/10.1186/1475-9276-13-37

[22] Midsundstad, T. and Bogen, H. (2014) Active Aging Policies between Individual Needs and Collective Goals: A Study of Aging Policies and Practices in Norway. Nordic Journal of Working Life Studies, 4, 139-158.

http://web.a.ebscohost.com/ehost/pdfviewer/pdfviewer?vid=6\&sid=9552fa59-4e9f-49bf-95e6-f215dfa22523\%40sessio nmgr4002\&hid $=4206$

[23] Yamane, D. (2000) Narrative and Religious Experience. Sociology of Religion, 61, 171-189.

http://www.jstor.org/stable/pdf/3712284 http://dx.doi.org/10.2307/3712284

[24] Ferrater-Mora, J. and Cohn, P. (1970) The Language of Religious Experience. International Journal of Philosophy and Religion, 1, 22-33. http://www.jstor.org/stable/40038510 http://dx.doi.org/10.1007/bf00136286

[25] Goffman, E. (1986) Frame Analysis: An Essay on the Organization of Experience. Northwestern University Press, Boston.

[26] Esteban, R. (2012-2013) Development of the QOL-APO: A Measure of Quality of Life among the Filipino Elderly from the Perspectives of the Elderly, Family and Healthcare Providers in the Philippines. Research Project Funded by the Department of Science and Technology-Philippine Council for Health Research and Development (DOSTPCHRD).

[27] Dominguez, J.C., Soriano, J.R., Magpantay, C.D., Orquisa, M.G.S., Solis, W.M., Reandelar, M.F. and Joson, M.L.C. (2014) Early Detection of Mild Alzheimer's Disease in Filipino Elderly: Validation of the Montreal Cognitive Assessment-Philippines (MoCA-P). Advances in Alzheimer's Disease, 3, 160-167. http://dx.doi.org/10.4236/aad.2014.34015

[28] Strauss, A. and Corbin, J. (1994) Grounded Theory Methodology: An Overview. In: Denzin, N. and Lincoln, Y., Eds., Handbook of Qualitative Research, Sage Publication, London, 273-285.

[29] Kaufman, S. (1986) The Ageless Self: Sources of Meaning in Late Life. University of Wisconsin, Madison.

[30] Butler, R.N. (1986) Dispelling Ageism: The Cross-Cutting Intervention. Annals of the American Academy of Political and Social Sciences, 503, 138-147. http://www.jstor.org/stable/1047223 http://dx.doi.org/10.1177/0002716289503001011

[31] Ilmarinen, J. (1997) Aging and Work-Coping with Strengths and Weaknesses. Scandinavian Journal of Work, Environment and Health, 23, 3-5. http://www.jstor.org/stable/40966685.

[32] Tuomi, K., Ilmarinen, J.K., Seitsamo, J., Huuhtanen, P., Martikainen, R., Nygård, C., et al. (1997) Summary of the Finnish Research Project (1981-1992) to Promote the Health and Work Ability of Aging Workers. Scandinavian Journal of Work, Environment and Health, 23, 66-71. http://www.jstor.org/stable/40966693

[33] Atchley, R. (1989) A Continuity Theory of Normal Aging. The Gerontologist, 29, 183-190. http://www.ncbi.nlm.nih.gov/pubmed/2519525 http://dx.doi.org/10.1093/geront/29.2.183

[34] Traphagan, J.W. (1998) Contesting the Transition to Old Age in Japan. Ethnology, 37, 333-350. http://www.jstor.org/stable/3773786 http://dx.doi.org/10.2307/3773786

[35] Ayabe, M., Yahiro, T., Yoshioka, M., Higuchi, H., Higaki., Y. and Tanaka, H. (2009) Objectively Measured AgeRelated Changes in the Intensity Distribution of Daily Physical Activity in Adults. Journal of Physical Activity \& Health, 6, 419-425. http://www.ncbi.nlm.nih.gov/pubmed/19842455

[36] Koren, C. (2011) Continuity and Discontinuity: The Case of Second Couplehood in Old Age. The Gerontologist, 51, 687-698. http://dx.doi.org/10.1093/geront/gnr018

[37] Butler, R.N. (1983) An Overview of Research on Aging and the Status of Gerontology Today. The Milbank Memorial Fund Quarterly Health and Society, 61, 351-361. http://www.jstor.org/stable/pdf/3349862 http://dx.doi.org/10.2307/3349862

[38] Butler, R.N. (1989) Dispelling Ageism: The Cross-Cutting Intervention. Annals of the American Academy of Political and Social Science, 503, 138-147. http://www.jstor.org/stable/1047223 
http://dx.doi.org/10.1177/0002716289503001011

[39] Kennedy, J. (2001) Unmet and Undermet Need for Activities of Daily Living and Instrumental Activities of Daily Living Assistance among Adults with Disabilities: Estimates from the 1994 and 1995 Disability Follow-Back Surveys. Medical Care, 39, 1305-1312. http://www.jstor.org/stable/pdf/3768103 http://dx.doi.org/10.1097/00005650-200112000-00006

[40] Smith, D.W., Hogan, A.J. and Rohrer, J.E. (1987) Activities of Daily Living as Quantitative Indicators of Nursing Effort. Medical Care, 25, 120-130. http://www.jstor.org/stable/3765511 http://dx.doi.org/10.1097/00005650-198702000-00005

[41] Cornwell, B., Laumann, E.O. and Schumm, L.P. (2008) The Social Connectedness of Older Adults: A National Profile. American Sociological Review, 73, 185-203. http://www.jstor.org/stable/pdf/25472522 http://dx.doi.org/10.1177/000312240807300201

[42] Esteban, R., Dominguez, J., Yumul, J., Natividad, B., Magpantay, C., Soriano, J.R., et al. (2013) Quality of Life among the Filipino Elderly: Glimpses from a Community. Philippine Neuroscience, 1, 15-24. http://philneuroscience.com/wp-content/uploads/2015/06/vol1-quality-of-life-among-erderly

[43] Cornwell, E.Y. and Waite, L.J. (2009) Social Disconnectedness, Perceived Isolation, and Health among Older Adults. Journal of Health and Social Behavior, 50, 31-48. http://hsb.sagepub.com/content/50/1/31.short?rss=1\&ssource=mfc http://dx.doi.org/10.1177/002214650905000103

[44] Versey, H.S. and Newton, N.J. (2013) Generativity and Productive Pursuits: Pathways to Successful Aging in Late Midlife African American and White Women. Journal of Adult Development, 20, 185-196. http://dx.doi.org/10.1007/s10804-013-9170-X

[45] Seitsamo, J. and Klockars, M. (1997) Aging and Changes in Health. Scandinavian Journal of Work, Environment and Health, 23, 27-35. http://www.jstor.org/stable/40966689

[46] Moura, A., Madureira, J., Alija, P., Fernandes, J.C., Oliveira, J.G., Lopez, M., et al. (2015) Effect of Aging in the Perception of Health-Related Quality of Life in End-Stage Renal Disease Patients under Online Hemodiafiltration. Aging and Disease, 6, 17-25. http://dx.doi.org/10.14336/AD.2014.0514

[47] Mandai, T., Ohashi, H., Ishii, K., Ono, M., Kishi, K., Fukushima, J., et al. (1997) Quality of Life and Disease Acceptance in Patients with Haemodialysis, Coronary Artery Bypass Graft Surgery and Mammary Cancer. Quality of Life Research, 6, 688.

[48] Arevalo-Rodriguez, I., Segura, O., Solà, I., Bonfill, X., Sanchez, E. and Alonso-Coello, P. (2014) Diagnostic Tools for Alzheimer's Disease Dementia and Other Dementias: An Overview of Diagnostic Test Accuracy Systematic Reviews. BMC Neurology, 14, 183. http://www.biomedcentral.com/1471-2377/14/183 http://dx.doi.org/10.1186/s12883-014-0183-2

[49] Tom, S., Hubbard, R., Crane, P., Haneuse, S., Bowen, J., McCormick, W. and Larson, E. (2015) Characterization of Dementia and Alzheimer's Disease in an Older Population: Updated Incidence and Life Expectancy with and without Dementia. American Journal of Public Health, 105, 408-413. http://dx.doi.org/10.2105/AJPH.2014.301935

[50] Mussele, S., Bekelaar, K., Le Bastard, N., Vermeiren, Y., Saerens, J., Somers, N., et al. (2013) Prevalence and Associated Behavioral Symptoms of Depression in Mild Cognitive Impairment and Dementia due to Alzheimer's Disease. International Journal of Geriatric Psychiatric, 28, 947-958. http://dx.doi.org/10.1002/gps.3909

[51] Passmore, M., Ho, A. and Gallagher, R. (2012) Behavioral Psychological Symptoms in Moderate to Severe Alzheimer's Disease: A Palliative Care Approach Emphasizing Recognition of Personhood and Preservation of Dignity. Journal of Alzheimer's Disease, 29, 1-13.

[52] Walter, J., Morris, J., Swier-Vosnos, A. and Pliskin, N. (2014).Effects of Severe Dementia on a Symptom Validity Measure. Clinical Neuropsychologist, 28, 1197-1208. http://dx.doi.org/10.1080/13854046.2014.960454

[53] Lee, S., Richie, C., Yaffe, K., Cenzer, I. and Barnes, D. (2014) Clinical Index to Predict Progression from Mild Cognitive Impairment to Dementia Due to Alzheimer's Disease. PLoS ONE, 9, 1-15.

[54] Osberg, L. (2005) Work and Well-Being in an Aging Society. Canadian Public Policy/Analyse de Politiques, 31, 413-420. http://www.jstor.org/stable/355236 http://dx.doi.org/10.2307/3552360

[55] Seitsamo, J. and Ilmarinen, J. (1997) Life-Style, Aging and Work Ability among Active Finnish Workers in 1981-1992. Scandinavian Journal of Work, Environment and Health, 23, 20-26. http://www.jstor.org/stable/40966688

[56] Smuts, B. (2006) What Are Friends For? In: Courtis, M., Ed., Taking Sides: Clashing Views on Controversial Issues in Physical Anthropology, McGrwhill/Dushkin, Dubuque, 163-171.

[57] Huxhold, O., Miche, M. and Schüz, B. (2014) Benefits of Having Friends in Older Ages: Effects of Informal Social Networks. Journal of Gerontology Series B: Psychological Sciences and Social Sciences, 69, 366-375. http://www.ncbi.nlm.nih.gov/pubmed/23682165 
http://dx.doi.org/10.1093/geronb/gbt029

[58] Kaufman, S.R. (1994) Old Age, Disease, and the Discourse on Risk: Geriatric Assessment in US Health. Anthropology Quarterly, New Series, 8, 430-447. http://www.jstor.org/stable/649089

[59] Flynn, C. and McCormack, B. (2010) Stimulating the Wrinkling and Aging of Skin with Multi-Layer Finite Element. Journal of Biomechanics, 43, 442-448. http://dx.doi.org/10.1016/j.jbiomech.2009.10.007

[60] Kalichman, L., Livshits, G. and Kobyliansky, E. (2006) Association between Morbidity and Skeletal Biomarkers of Biological Aging. Human Biology, 78, 77-88. http://dx.doi.org/10.1353/hub.2006.0025

http://web.a.ebscohost.com/ehost/pdfviewer/pdfviewer?vid=18\&sid=5a81e8ff-9abf-4e87-bf7a-48e6a7bf9405\%40sessi onmgr4005\&hid=4109

[61] Boyd, S.L. and Treas, J. (1989) Family Care of the Frail Elderly: A New Look at "Women in the Middle”. Women's Studies Quarterly, 17, 66-74. http://www.jstor.org/stable/40003979

[62] Avlund, K. (2013) Fatigue in Older Populations. Fatigue: Biomedicine, Heath and Behavior, 1, 43-63. http://www.tandfonline.com/doi/pdf/10.1080/21641846.2012.746200 http://dx.doi.org/10.1080/21641846.2012.746200

[63] Edgerton, T. (2013) Self-Reported Aging-Related Fatigue: A Concept Description and Its Relevance to Physical Therapist Practice. Physical Therapy, 93, 1403-1413. http://dx.doi.org/10.2522/ptj.20130011

[64] Fried, L.P., Tangen, C.M., Walston, J., Newman, A.B., Hirsch, C., Gottdiener, J., et al. (2001) Frailty in Older Adults. The Journals of Gerontology Series A: Biological Sciences and Medical Sciences, 56, M146-M157. http://biomedgerontology.oxfordjournals.org/content/56/3/M146.full http://dx.doi.org/10.1093/gerona/56.3.M146

[65] Liu, H. (2015) Aging and Chronic Diseases as Independent Causative Factor for Death and Programmed Onset of Chronic Disease. Archives of Gerontology and Geriatrics, 60, 178-182. http://dx.doi.org/10.1016/j.archger.2014.11.002

[66] Adeniyi, A.F., Ogwumiki, O.O., Akinwonmi, A.O. and Fasanmade, A.A. (2014) Links between Adiposity, Physical Activity and Self-reported Fatigue in Patients with Type 2 Diabetes Mellitus. International Journal of Diabetes in Developing Countries, 34, 144-149. http://dx.doi.org/10.1007/s13410-013-0175-6

[67] Ku, G.M.V. and Kegels, G. (2014) A Cross-Sectional Study of the Differences in Diabetes Knowledge, Attitudes, Perceptions and Self-Care Practices as Related to Assessment of Chronic Illness Care among People with Diabetes Consulting in a Family Physician-Led Hospital-Based First Line Health Service and Local Government Health Unit-Based Health Centers in the Philippines. Asia Pacific Family Medicine, 13, 1-18. http://dx.doi.org/10.1186/s12930-014-0014-z

[68] Stone, R.I. (1989) The Feminization of Poverty among the Elderly. Women's Studies Quarterly, 17, 20-34. http://www.jstor.org/stable/40003975

[69] Smeeding, T.M. and Sandström, S. (2005) Poverty and Income in Old Age: A Cross-National View of Low Income Older Women. Working Paper No. 398, Luxemburg Income Study Working Papers Series, Luxemburg Income Study (LIS), Luxembourg, 18 p. http://hdl.handle.net/10419/95568

[70] Wenger, G.C., Davies, R., Shantamasebi, S. and Scott, A. (1996) Social Isolation and Loneliness in Old Age: Review and Model Refinement. Ageing and Society, 16, 333-358. http://eprints.lancs.ac.uk/19681/1/download.pdf\%20?iframe=true\&width=100\%\&height=100\% http://dx.doi.org/10.1017/S0144686X00003457

[71] Hutchison, J. and Smith, A., Eds. (1996) Ethnicity. Oxford University Press, Oxford.

[72] Kuper, A. (1999) Among the Anthropologists: History and Context in Anthropology. The Athlone Press, London.

[73] Alcina, I.F., Kobak, C.J. and Gutierrez, L. (2004) History of the Bisayan People in the Philippine Islands. 2 Volumes, UST Publishing House, Manila.

[74] Frake, C.O. (1955) Social Organization and Shifting Agriculture among the Sindangan Subanun. Ph.D. Thesis, Yale University, New Haven.

[75] Mednick, M. (1965) Encampment on the Lake: The Social Organization of a Moslem-Philippine (Moro). Ph.D. Thesis, Yale University, New Haven.

[76] Jocano, F.L. (1968) Sulod Society: A Study in the Kinshp System and Social Organization of a Mountain People of Central Panay. University of the Philippines Press, Quezon City. http://dx.doi.org/10.5962/bhl.title.82726

[77] Go, S.P. (1994) The Present and Future of the Family in the Philippines. International Journal on World Peace, 11, 61-75. http://www.jstor.org/stable/20752000

[78] Sun, J. (2013) Chinese Older Adults Taking Care of Grandchildren: Practices and Policies for Productive Aging. Aging Institute, 38, 58-70. http://dx.doi.org/10.1007/s12126-012-9161-4 
[79] Williams, L. and Domingo, L.J. (1993) The Social Status of Elderly Women and Men within the Filipino Family. Journal of Marriage and Family, 55, 415-426. http://www.jstor.org/stable/352812 http://dx.doi.org/10.2307/352812

[80] Casterline, J., Williams, L., Hermalin, A., Cheng, M., Chayovan, N., Cheung, P., et al. (1992) Differences in the Living Arrangements of the Elderly in Four Asian Countries: The Interplay of Constraints and Preferences. Comparative Study of the Elderly in Asia: Research Reports, 30 April-2 May 1992, Population Studies Center, Ann Arbor, 50 p. http://vivo.cornell.edu/display/AI-24120246273

[81] Abenoja, M.K. (1990) World's Apart? Gender Divide in the Conditions of Elderly Filipinos. Philippine Quarterly of Culture and Society, 18, 275-290. http://www.jstor.org/stable/29792028

[82] Kim, I.K. and Kim, C. (2003) Patterns of Family Support and the Quality of Life of the Elderly. Social Indicators Research, 62, 437-454. http://dx.doi.org/10.1007/978-94-017-0281-2_21

[83] Hermalin, A., Ofstedal, M.B. and Lee, M.-L. (1992) Characteristics of Children and Intergenerational Transfers. Research Report No. 92-21, Proceedings of the Annual Meeting of the Population Association of America, Denver, 30 April-2 May 1992, $50 \mathrm{p}$.

[84] Zhang, X.L. and Huang, D.Y. (2007) A Temporal Analysis of the Consciousness of Filial Piety. Frontiers of Philosophy in China, 2, 309-335. http://www.jstor.org/stable/27823297 http://dx.doi.org/10.1007/s11466-007-0020-4

[85] Kaut, C. (1961) Utang Na Loob: A System of Contractual Obligation among Tagalogs. Southwestern Journal of Anthropology, 17, 256-272. http://www.jstor.org/stable/3629045

[86] Hollnsteiner, M.R. (1961) Reciprocity in the Lowland Philippines. Philippine Studies, 9, 387-413. http://www.jstor.org/stable/42720500

[87] Brandewie, E. (1973) Family Size and Kinship Pressures in the Philippines. Philippine Quarterly of Culture and Society, 1, 6-18. http://www.jstor.org/stable/29791036

[88] Ligo-Ralph, V. (1990) Some Theses Concerning the Filipino Value System. Philippine Quarterly of Culture and Society, 18, 149-161. http://www.jstor.org/stable/29792016

[89] Hess, B.B. and Waring, J.M. (1978) Changing Patterns of Aging and Family Bonds in Later Life. The Family Coordinator, 27, 303-314. http://www.jstor.org/stable/583432 http://dx.doi.org/10.2307/583432

[90] Siebert, D.C., Mutran, E.J. and Reitzes, D.C. (1999) Friendship and Social Support: The Importance of Role Identity to Aging Adults. Social Work, 44, 522-533. http://dx.doi.org/10.1093/sw/44.6.522 http://web.a.ebscohost.com/ehost/pdfviewer/pdfviewer?vid=3\&sid=678a6fc6-89e1-4ca0-94a1-ceb79c4e778a\%40sessi onmgr4001\&hid $=4214$

[91] Baskin, C. and Davey, C.J. (2015) Grannies, Elders, and Friends: Aging Aboriginal Women in Toronto. Journal of Gerontological Social Work, 58, 46-65. http://dx.doi.org/10.1080/01634372.2014.912997

[92] Ayuso Sánchez, L. (2013) Personal Network Supporting Widowhood in Spain. Journals of Gerontology Series B: Psychological Sciences and /Social Sciences, 68, 644-652.

[93] Warburton, J. and Grassman, E. (2011) Variations in Older People’s Social and Productive Ageing Activities across Different Social Welfare Regimes. International Journal of Social Welfare, 20, 180-191. http://dx.doi.org/10.1111/j.1468-2397.2009.00691.x

[94] World Values Survey Homepage (2009) http://www.worldvaluessurvey.org.

[95] http://tzuchi.org.ph/home//.

[96] Donnelly, E. and Hinterlong, J. (2009) Changes in Social Participation and Volunteer Activity among Recently Widowed Older Adults. The Gerontologist, 50, 158-169. http://gerontologist.oxfordjournals.org/content/50/2/158.long http://dx.doi.org/10.1093/geront/gnp103

[97] Cornwell, B. (2009) Network Bridging Potential in Late Life: Life-Course Experiences and Social Network Position. Journal of Aging, 21, 129-154. http://www.ncbi.nlm.nih.gov/pmc/articles/PMC2742371/pdf/nihms129617

[98] Welte, T. (1994) Individual Preferences and Advance Directives. Hastings Center Report: Special Supplement, 24, S5S8.

[99] Franklin, N. (2009) Lifestyle and Successful Aging. American Journal of Lifestyle Medicine, 3, 6-11. http://ajl.sagepub.com/content/3/1/6.abstract http://dx.doi.org/10.1177/1559827608326125

[100] Weiss, P. (1963) Religious Experience. The Review of Metaphysics, 17, 3-17. http://www.jstor.org/stable/20123981

[101] Ferris, A.L. (2002) Religion and the Quality of Life. Journal of Happiness Studies, 3, 199-215. http://link.springer.com/article/10.1023/A\%3A1020684404438 
[102] Idler, E.L. (1995) Religion, Health, and Nonphysical Senses of Self. Social Forces, 74, 683-704. http://www.jstor.org/stable/2580497 http://dx.doi.org/10.1093/sf/74.2.683

[103] Hadaway, C.K. (1978) Life Satisfaction and Religion: A Reanalysis. Social Forces, 57, 636-643. http://www.jstor.org/stable/2577686 http://dx.doi.org/10.1093/sf/57.2.636

[104] Idler, E., McLaughlin, J. and Stanislav, K. (2009) Religion and Quality of Life in the Late Year of Life. Journal of Gerontology: Social Science, 64b, 528-537. http://dx.doi.org/10.1093/geronb/gbp028

[105] Seki, K. (2002) Fiesta, Patron Saint, and the Concept of Gahum: A Preliminary Study of the Folk Notion of Power among Cebuano Migrant Fisherfolk. Philippine Quarterly of Culture and Society, 30, 111-137. http://www.jstor.org/stable/29792504

[106] Peterson, W. (2007) Holy Week in the "Heart of the Philippines": Spirituality, Theatre, and Community in Marinduque's Moriones Festival. Asian Theatre Journal, 24, 309-337. http://www.jstor.org/stable/pdf/27568417 http://dx.doi.org/10.1353/atj.2007.0039

[107] Tiatco, A.P. and Bonifacio-Ramolete, A. (2008) Cutud's Ritual of Nailing on the Cross: Performance of Pain and Suffering. Asian Theatre Journal, 25, 58-76. http://www.jstor.org/stable/27568435 http://dx.doi.org/10.1353/atj.2008.0014

[108] Mojares, R.B. (2002) Stalking the Virgin: The Genealogy of the Cebuano Virgin of Guadalupe. Philippine Quarterly of Culture and Society, 30, 138-171. http://www.jstor.org/stable/29792505

[109] Heydari-Fard, K.J., Bagheri-Nesami, M., Shirvani, M. and Mohammadpour, R.-A. (2014) Association between Quality of Life and Religious Coping in Older People. Nursing Older People, 26, 24-29. http://web.b.ebscohost.com/ehost/pdfviewer/pdfviewer?vid=3\&sid=afbc2d51-fac1-4b27-b48e-e80442d760c4\%40sessi onmor112\&hid $=128$ http://dx.doi.org/10.7748/nop2014.03.26.3.24.e496

[110] Balgos, L. (1998) Mga Ritwal, Sumpa, at Panata: Kalipunan Ng Tatlong Maikling Nobela: Sumpa, Ritwal, Panata. University of the Philippines Press, Quezon City.

[111] Overall, C. (2006) Old Age and Ageism, Impairment and Ableism: Exploring the Conceptual and Material Connections. NWSA Journal, 18, 126-137. http://www.jstor.org/stable/pdf/4317189 http://dx.doi.org/10.2979/nws.2006.18.1.126

[112] Mendes, F. (2013) Active Aging: A Right or Duty? Health Sociology Review, 22, 174-185. http://dx.doi.org/10.5172/hesr.2013.22.2.174

[113] Connel, M. and Gibson, G. (1997) Racial, Ethnic, and Cultural Differences in Dementia Care Giving: Review and Analysis. The Gerontologist, 37, 355-364. http://gerontologist.oxfordjournals.org/content/37/3/355.full http://dx.doi.org/10.1093/geront/37.3.355

[114] Nahemow, N. (1979) Residence, Kinship and Social Isolation among the Aged Bagenda. Journal of Marriage and Family, 41, 171-183. http://www.jstor.org/stable/351741 http://dx.doi.org/10.2307/351741

[115] Demerath, N.J. and Roof, W.C. (1976) Religion-Recent Strands in Research. Annual Review of Sociology, 2, 19-33. http://www.jstor.org/stable/2946084 http://dx.doi.org/10.1146/annurev.so.02.080176.000315

[116] Campbell, A., Converse, P.E. and Rodgers, W. (1976) The Quality of American Life. Russell Sage, New York. http://gerontologist.oxfordjournals.org/content/37/3/355 